JOAL, (JOURNAL, (DF APPIIII) LINGUISIIICS ANI) LI'TERA'TURE)

Vol. 5 No. 2, 2020

ISSN (print): 2502-7816; ISSN (online): 2503-524X

Available online at https:/ / ejournal.unib.ac.id/index.php/joall/index

doi: http://dx.doi.org/10.33369/joall.v5i2.10753

\title{
FEASIBILITY TEST OF ENGLISH INSTRUCTIONAL MATERIALS FOR SECRETARIES THROUGH MOODLE
}

\author{
Didik Hariyadi Raharjo \\ Akademi Sekretari Budi Luhur \\ Corresponding email: didik.hariyadiraharjo@budiluhur.ac.id
}

\begin{abstract}
This research aimed to investigate the feasibility of EFS instructional material developed for ASTRI Budi Luhur students. The research was designed as qualitative and quantitative (mixed) approach. The method used in this study was the Delphi method, and the data were collected through questionnaires and interviews. Quantitative data were analyzed based on eligibility categories while qualitative data were analyzed to draw conclusions. The feasibility of the product of this research was examined by two experts in English for Specific Purposes (ESP) and instructional materials. The result showed that the instructional material was feasible with several improvements. Product feasibility test in this research was carried out three times. Each test was carried out after revising the draft of instructional materials based on input provided by the experts. In the last feasibility test, the experts gave a score of 3.7 for the syllabus and 3.7 for the developed instructional material, indicating that both the syllabus and EFS instructional material developed were very feasible to be applied in EFS learning in ASTRI Budi Luhur Jakarta.
\end{abstract}

Keywords: Feasibility Test, Syllabus, Instructional Material, Moodle

\section{INTRODUCTION}

A secretary was someone who could be trusted to help and conduct administrative activities that support the managerial activities of the superiors or company operational activities (Yatimah, 2009). For a secretary, English was very important to complete a variety of tasks because English was an international language. It was used for communication in many business activities in the world (Salisna, Harahap, \& Sofyan, 2019). For this reason the Secretarial Academy (ASTRI) of Budi Luhur as one of the secretarial academies in Jakarta made English as one of the main skills for all students. For this reason, the English courses in ASTRI Budi Luhur had a large number; those were 5 courses with a total of 18 credits. However, the 


\section{Didik Hariyadi Raharjo}

results of the English competency test conducted in the end of the student lecture in the last few years showed poor results and need to be improved, especially in speaking and writing skills.

One of the causes of the lack of ASTRI Budi Luhur students' English proficiency was the condition of instructional material available at ASTRI Budi Luhur. Mc.Grath (2013) stated that instructional materials play an important role in a process and learning outcomes. One of the existing English instructional materials in ASTRI Budi Luhur that was needed to be developed was English for Secretary (EFS). Based on the preliminary observation of the existing EFS instructional material in ASTRI Budi Luhur, the researcher could conclude that it could be categorized as inappropriate to use in EFS teaching learning process and it still needed to be developed if it was viewed from the perspective of: objectives and approaches; design and organization; language content; language skills and topics. The existing EFS instructional material in ASTRI Budi Luhur did not provide listening material and it was not equipped with a complete package of instructional material such as manuals for students and lecturers or other multimedia equipment. Nurhamsih \& Syahrial (2018) stated that the textbook should be accompanied with other teaching learning media (workbook, cassettes, and CD) so that the materials can be as authentic as possible and very useful.

Meanwhile, Martins, Levis, \& Borges, (2016) stated that instructional materials were intended to meet the needs of learners. Furthermore Cunnigsworth (2000) showed that instructional materials should be in accordance with the needs of the learners and in accordance with the aims and objectives of the language learning program implemented. In line with previous opinions, Beth (2019) defined instructional material as a spectrum that was used by teachers in the classroom to support certain learning objectives, as stated in the learning plan. Instructional material referred to everything that was used by instructors or learners to facilitate learning (Tomlinson, 2011); (Richards \& Schmidt, 2010).

Therefore, by observing the results of the initial research above, the researcher could conclude that there was a gap between the ideal conditions of EFS instructional material for secretarial academy students and the real conditions of existing EFS instructional material in ASTRI Budi Luhur. For this reason, researcher developed an EFS instructional material based on a needs analysis that had been done in the previous research. The instructional material was developed in the form of fully online learning and delivered in synchronous learning. The instructional material was developed to improve 4 students' English skills in a secretarial context. This instructional material was used as the main instructional material in EFS learning. This EFS instructional material package consisted of syllabus and online instructional 
material. This online instructional material was developed through the Moodle platform.

The main objective of this research was to conduct a feasibility test of the syllabus and EFS instructional material that have been developed. Syllabus was a document that contains what needs to be learned (Hutchinson \& Waters, 1988). Syllabus was a specification of what will be taught in a language program and the sequence that must be taught (Nunan, 2004). All syllabus assessments developed are based on the principles of syllabus preparation in IQF which include: Basis of development; Identity; Course Learning Outcome; Lesson Learning Outcome; Evaluation Indicator; Theme; Learning Experience; Evaluation Material; Material Design; Learning Method; Bibliography; Evaluation; and Time of Achievement (Nurwardani, et. al, 2016). As for the assessment of the feasibility of instructional material in this research was based on the concept of instructional material evaluation proposed by Cunningsworth (2000) as could be seen in the table below:

Table 1: Cunningsworth Quick Reference Checklist for Evaluation

\begin{tabular}{|c|c|}
\hline Aims and Approach & $\begin{array}{l}\text { - What are the aims of the English programme? } \\
\text { - Do the aims of the coursebook correspond closely with the aims } \\
\text { of the teaching programme and with the needs of the learners? } \\
\text { does the material fit your syllabus? } \\
\text { - Is the coursebook flexible? Does it allow different teaching and } \\
\text { learning styles? } \\
\text { - Etc. }\end{array}$ \\
\hline Coursebook Package & $\begin{array}{l}\text { - What components make up the total course package (students' } \\
\text { books, teachers' books, workbooks, cassettes, etc)? } \\
\text { - If it is a new course, are all components published and } \\
\text { available? If it is not yet complete, will the next levels be ready } \\
\text { when you need them? } \\
\text { - How well do the different parts of the package relate to the } \\
\text { whole? Is there an overall guide to using the package? Is there } \\
\text { cross-referencing between the different parts? } \\
\text { - Etc. }\end{array}$ \\
\hline Methodology & $\begin{array}{l}\text { - What approach/approaches to language learning are taken by } \\
\text { the coursebook? } \\
\text { - Is this appropriate to the learning/teaching situation? } \\
\text { - Does it encourage an inductive or deductive approach to } \\
\text { learning - or a balance of both? } \\
\text { - How does it approach the teaching of skills and } \\
\text { communication? } \\
\text { - Etc. }\end{array}$ \\
\hline Language Content & $\begin{array}{l}\text { - To what extent is the content selected according to structure, } \\
\text { functions, situations, topics, other? } \\
\text { - Is any one of the above predominant as the basis of selection of } \\
\text { content? }\end{array}$ \\
\hline
\end{tabular}


- How well does the coursebook balance the above factors in selecting content and to what extent is it successful in integrating the different approaches?

- Etc.

$\begin{array}{ll}\text { - } & \text { Are all four skills adequately covered, bearing in mind your } \\ & \text { course aims and syllabus requirements? } \\ \text { - Is practice in all four skills included? If so, is it balanced? } \\ \text { - If not, which skills are omitted, and why? } \\ \text { - Is there material for integrated skills work? } \\ \text { - Etc. } \\ \text { - Is there adequate guidance for the teachers who will be using } \\ \text { - the coursebook and its supporting materials? } \\ \text { - Do the writers set out and justify the basic premises and } \\ \text { - } \text { - Are keys to exercises given? } \\ \text { - Etc. }\end{array}$

Some researches and development of EFS instructional material had been done before, but the researcher had not found one of the studies that were aimed to develop EFS instructional material through Moodle platform which focused on 4 English skills. Almost all previous research was aimed to develop printed instructional material. Some design and development research that used the Moodle platform was usually only aimed to improve one of 4 English skills (listening, speaking, reading and writing).

One example of researches about EFS instructional material was conducted by (Giri, Artini, \& Padmadewi, 2018) with the title "Developing Research and Development of English for Specific Purposes: Specific Reference of English for Secretary". The results of this research indicated that based on the results of observations, interviews, and questionnaires, the researchers developed instructional material consisting of 8 units. The feasibility of this instructional material was analyzed through a questionnaire by experts and students. The results of the feasibility test showed that the instructional material developed had a good quality and there was a little revision to be done. The developed EFS instructional material also received a positive feedback from the students. However, the instructional material product produced was printed books and there was no information regarding the package of the product.

\section{METHODS}

This research approach could be categorized as qualitative and quantitative research (mixed method). Mixed method was a research by combining two forms of research approaches, namely qualitative and quantitative (Cresswell, Plano-Clark, Gutmann, \& Hanson, 2003); (Sugiyono, 2016). Meanwhile, the subjects of this study were 2 experts consisting of 1 ESP 
expert and 1 expert instructional material development. Furthermore, the experts involved in the research can be seen in the table below:

Table 2: List of Feasibility Test Experts

\begin{tabular}{cll}
\hline No & \multicolumn{1}{c}{ Name } & \multicolumn{1}{c}{ Expertise } \\
\hline 1 & Prof. Dr. Endang Fauziati, & $\begin{array}{l}\text { Expert in English Instructional materials } \\
\text { for specific purposes from } \\
\\
\text { M.Hum. }\end{array}$ \\
\hline 2 & Prof. Dr. Joko Nurkammadiyah University of Surakarta \\
\hline & & $\begin{array}{l}\text { Expert in developing online instructional } \\
\text { materials through Moodle from Sebelas } \\
\text { Maret State University of Surakarta }\end{array}$ \\
\hline
\end{tabular}

Meanwhile, the method used in this research was Delphi method. The Delphi method was aimed to obtain the agreement of experts who had high reliability values through a series of questionnaires accompanied by providing feedback on the agreement (Mahajan, Linstone, \& Turoff, 1976). The research instruments used in this research were questionnaires and interviews. The questionnaire given to the experts consisted of a syllabus questionnaire and EFS instructional material feasibility questionnaires. Meanwhile, interview was conducted to confirm the assessment of the experts given through the questionnaires. The feasibility questionnaire given to the experts was analyzed quantitatively. It used a Likert scale. The following table was the categories of eligibility for syllabus and EFS instructional material through Moodle developed.

Table 3: Feasibility Test Category

\begin{tabular}{cc}
\hline Average Score & Category \\
\hline $1,00-1,75$ & Not Feasible \\
\hline $1,76-2,50$ & Less Feasible \\
\hline $2,51-3,25$ & Feasible \\
\hline $3,26-4,00$ & Very Feasible \\
\hline
\end{tabular}

The results of the interview were described, concluded and compared with the results of the questionnaire that has been obtained. After that, based on qualitative and quantitative data obtained, the researcher could conclude the feasibility of EFS instructional material that has been developed.

\section{FINDINGS}

In this research, the researcher conducted 3 times the feasibility test on the developed EFS instructional material. The due diligence involved 2 experts consisting of 1 ESP expert and 1 expert on developing teaching online materials. The feasibility test was carried out on the syllabus and instructional materials that were developed in draft 1,2 and 3. Each draft was developed to improve upon the previous draft based on expert advice.

As explained earlier, the instructional material developed was EFS instructional material for ASTRI Budi Luhur Students. This instructional 


\section{Didik Hariyadi Raharjo}

material was an online instructional material that was delivered in full online learning and synchronous learning. Genova (2019) described elearning as a new environment in which both instructors and learners use it to interact with each other. Whereas Clark \& Mayer (2011) defined elearning as teaching delivered through digital equipment such as computers or mobile devices intended to support learning. Synchronous Learning was a learning process carried out by lecturers and learners at the same time so as to allow direct interaction in the learning process either through the internet or intranet.

This instructional material was intended to develop 4 English skills (listening, speaking, reading and writing) in the context of secretarial work. This instructional material adopted inquiry learning methods to provide broader opportunities for students in the learning process. All learning plans in this instructional material were adjusted to IQF level 5 for diploma III graduates.

The following table was the result of the experts' evaluation of the EFS syllabus draft 1 developed:

Table 4: Feasibility Test of EFS Syllabus Draft 1

\begin{tabular}{clcccc}
\hline \multirow{2}{*}{ No } & \multicolumn{1}{c}{ Dimension } & \multicolumn{2}{c}{ Score } & \multirow{2}{*}{ Average } & \multirow{2}{*}{ Explanation } \\
\cline { 2 - 4 } & Expert 1 & Expert 2 & & \\
\hline 1 & Basis of development & 4 & 4 & 4 & Very Feasible \\
\hline 2 & Identity & 4 & 4 & 4 & Very Feasible \\
\hline 3 & $\begin{array}{l}\text { Course Learning } \\
\text { Outcome }\end{array}$ & 4 & 4 & 4 & Very Feasible \\
\hline 4 & $\begin{array}{l}\text { Lesson Learning } \\
\text { Outcome }\end{array}$ & 4 & 4 & 4 & Very Feasible \\
\hline 5 & Evaluation Indicator & 3 & 3 & 3 & Feasible \\
\hline 6 & Theme & 4 & 3 & 3,5 & Very Feasible \\
\hline 7 & Learning Experience & 3 & 3 & 3 & Feasible \\
\hline 8 & Evaluation Material & 3 & 3 & 3 & Feasible \\
\hline 9 & Material Design & 3 & 4 & 3,5 & Very Feasible \\
\hline 10 & Learning Method & 3 & 3 & 3 & Feasible \\
\hline 11 & Bibliography & 4 & 4 & 4 & Very Feasible \\
\hline 12 & Evaluation & 3 & 4 & 3,5 & Very Feasible \\
\hline 13 & Time of Achievement & 3 & 3 & 3 & Feasible \\
\hline$\quad$ Average & & & 3,5 & Very Feasible \\
\hline
\end{tabular}

Based on expert judgment, it could be concluded that the EFS syllabus draft 1 developed had a score of 3.5 and it showed that the syllabus was very suitable for use in the learning process. Furthermore, based on the interview, the researcher had to change the syllabus in assessment indicators and the form of syllabus.

Furthermore, the expert's evaluation of the EFS instructional material developed in draft 1 could be seen in the following table: 
Feasibility Test of English Instructional Materials for...

Table 5: Feasibility Test of Instructional Material Draft 1

\begin{tabular}{|c|c|c|c|c|c|}
\hline Dimension & Indicators & 1 & 2 & Average & Explanation \\
\hline \multirow{3}{*}{$\begin{array}{l}\text { Aim and } \\
\text { Approach }\end{array}$} & Objectives & 3 & 3 & 3 & Feasible \\
\hline & Student's need & 3 & 3 & 3,5 & Very Feasible \\
\hline & Learning style & 3 & 3 & 3 & Feasible \\
\hline \multirow{3}{*}{$\begin{array}{l}\text { Design and } \\
\text { Organization }\end{array}$} & Course package & 4 & 3 & 3,5 & Very Feasible \\
\hline & Content organization & 3 & 3 & 3 & Feasible \\
\hline & Content sequencing & 3 & 3 & 3 & Feasible \\
\hline \multirow{2}{*}{$\begin{array}{l}\text { Language } \\
\text { Content }\end{array}$} & Grammar & 3 & 3 & 3 & Feasible \\
\hline & Vocabulary & 3 & 3 & 3 & Feasible \\
\hline \multirow[t]{4}{*}{ Skills } & Listening & 3 & 4 & 3,5 & Very Feasible \\
\hline & Speaking & 3 & 4 & 3,5 & Very Feasible \\
\hline & Reading & 3 & 3 & 3 & Feasible \\
\hline & Writing & 3 & 3 & 3 & Feasible \\
\hline \multirow[t]{3}{*}{ Topic } & Interesting material & 4 & 4 & 4 & Very Feasible \\
\hline & Material variety & 4 & 4 & 4 & Very Feasible \\
\hline & $\begin{array}{l}\text { Awareness and } \\
\text { experience. }\end{array}$ & 3 & 4 & 3,5 & Very Feasible \\
\hline \multirow[t]{2}{*}{ Methodology } & Suitability of approach & 3 & 3 & 3 & Feasible \\
\hline & Suitability of techniques & 4 & 4 & 4 & Very Feasible \\
\hline & Average & & & 3,25 & Feasible \\
\hline
\end{tabular}

In the evaluation of instructional material this time, the experts gave a score of 3.25; it showed that the instructional material was feasible to be used in the EFS learning process. Based on interviews conducted, the researcher had to the entire instruction sentences in the exercises and evaluations and added a reference sub section to the EFS instructional material website.

After making various changes to the syllabus and instructional materials based on the experts' recommendations on the evaluation of instructional material draft 1 , the researcher returned to conduct a feasibility test on the EFS instructional material draft 2 that had been developed. The following table was the result of the assessment syllabus from the 2 experts:

Table 6: Feasibility Test of EFS Syllabus Draft 2

\begin{tabular}{clcccc}
\hline \multirow{2}{*}{ No } & \multicolumn{1}{c}{ Dimension } & \multicolumn{2}{c}{ Score } & \multirow{2}{*}{ Average } & \multirow{2}{*}{ Explanation } \\
\cline { 2 - 4 } & & Expert 1 & Expert 2 & & \\
\hline 1 & Basis of development & 4 & 4 & 4 & Very Feasible \\
\hline 2 & Identity & 4 & 4 & 4 & Very Feasible \\
\hline 3 & Course Learning Outcome & 4 & 4 & 4 & Very Feasible \\
\hline 4 & Lesson Learning Outcome & 4 & 4 & 4 & Very Feasible \\
\hline 5 & Evaluation Indicator & 4 & 4 & 4 & Very Feasible \\
\hline 6 & Theme & 4 & 3 & 3,5 & Very Feasible \\
\hline 7 & Learning Experience & 3 & 3 & 3 & Feasible \\
\hline 8 & Evaluation Material & 3 & 3 & 3 & Feasible \\
\hline 9 & Material Design & 3 & 4 & 3,5 & Very Feasible \\
\hline 10 & Learning Method & 3 & 3 & 3 & Feasible \\
\hline
\end{tabular}




\begin{tabular}{|c|c|c|c|c|c|}
\hline \multirow{2}{*}{ No } & \multirow{2}{*}{ Dimension } & \multicolumn{2}{|c|}{ Score } & \multirow{2}{*}{ Average } & \multirow{2}{*}{ Explanation } \\
\hline & & Expert 1 & Expert 2 & & \\
\hline 11 & Bibliography & 4 & 4 & 4 & Very Feasible \\
\hline 12 & Evaluation & 3 & 4 & 3,5 & Very Feasible \\
\hline 13 & Time of Achievement & 3 & 3 & 3 & Feasible \\
\hline & $\overline{\mathrm{Av}}$ & & & 3,5 & Very Feasible \\
\hline
\end{tabular}

In this assessment, the experts gave a score of 3.5 which means that the syllabus draft 2 was appropriate to be used in the EFS learning process. Furthermore, based on the results of interview the researcher could conclude that the syllabus was very good in quality and was suitable for use in EFS learning.

Furthermore, the result of the experts' assessment of EFS instructional material draft 2 could be seen in the following table:

Table 7: Feasibility Test of Instructional material Draft 2

\begin{tabular}{|c|c|c|c|c|c|}
\hline Dimension & Indicators & 1 & 2 & Average & Explanation \\
\hline \multirow{3}{*}{$\begin{array}{l}\text { Aim and } \\
\text { Approach }\end{array}$} & Objectives & 3 & 3 & 3 & Feasible \\
\hline & Student's need & 3 & 3 & 3,5 & Very Feasible \\
\hline & Learning style & 3 & 3 & 3 & Feasible \\
\hline \multirow{3}{*}{$\begin{array}{l}\text { Design and } \\
\text { Organization }\end{array}$} & Course package & 4 & 4 & 4 & Very Feasible \\
\hline & Content organization & 3 & 3 & 3 & Feasible \\
\hline & Content sequencing & 3 & 3 & 3 & Feasible \\
\hline \multirow{2}{*}{$\begin{array}{l}\text { Language } \\
\text { Content }\end{array}$} & Grammar & 3 & 3 & 3 & Feasible \\
\hline & Vocabulary & 3 & 3 & 3 & Feasible \\
\hline \multirow[t]{4}{*}{ Skills } & Listening & 4 & 4 & 4 & Very Feasible \\
\hline & Speaking & 4 & 4 & 4 & Very Feasible \\
\hline & Reading & 4 & 4 & 4 & Feasible \\
\hline & Writing & 4 & 4 & 4 & Feasible \\
\hline \multirow[t]{3}{*}{ Topic } & Interesting material & 4 & 4 & 4 & Very Feasible \\
\hline & Material variety & 4 & 4 & 4 & Very Feasible \\
\hline & $\begin{array}{l}\text { Awareness and } \\
\text { experience. }\end{array}$ & 3 & 4 & 3,5 & Very Feasible \\
\hline \multirow[t]{3}{*}{ Methodology } & Suitability of approach & 3 & 3 & 3 & Feasible \\
\hline & Suitability of techniques & 4 & 4 & 4 & Very Feasible \\
\hline & Average & & & 3,5 & Feasible \\
\hline
\end{tabular}

In this assessment, the experts gave a score of 3.5 which meant that the instructional material was already very feasible to be used in the EFS learning process. In the interview process, the experts also did not provide many comments about the instructional material.

Based on these findings in small group test conducted, the researcher developed the EFS draft 3 instructional materials. For this reason, the researcher conducted a feasibility test by involving the experts. The results of the experts' assessment of the developed EFS syllabus draft 3 can be seen in the following table: 
Feasibility Test of English Instructional Materials for...

Table 8: Feasibility Test of EFS Syllabus Draft 3

\begin{tabular}{clcccc}
\hline \multirow{2}{*}{ No } & \multirow{2}{*}{ Dimension } & \multicolumn{2}{c}{ Score } & \multirow{2}{*}{ Average } & \multirow{2}{*}{ Explanation } \\
\cline { 3 - 4 } & & Expert 1 & Expert 2 & & \\
\hline 1 & Basis of development & 4 & 4 & 4 & Very Feasible \\
\hline 2 & Identity & 4 & 4 & 4 & Very Feasible \\
\hline 3 & Course Learning Outcome & 4 & 4 & 4 & Very Feasible \\
\hline 4 & Lesson Learning Outcome & 4 & 4 & 4 & Very Feasible \\
\hline 5 & Evaluation Indicator & 4 & 4 & 4 & Feasible \\
\hline 6 & Theme & 4 & 3 & 3,5 & Very Feasible \\
\hline 7 & Learning Experience & 4 & 3 & 3,5 & Feasible \\
\hline 8 & Evaluation Material & 4 & 3 & 3,5 & Feasible \\
\hline 9 & Material Design & 3 & 4 & 3,5 & Very Feasible \\
\hline 10 & Learning Method & 4 & 4 & 4 & Feasible \\
\hline 11 & Bibliography & 4 & 4 & 4 & Very Feasible \\
\hline 12 & Evaluation & 3 & 4 & 3,5 & Very Feasible \\
\hline 13 & Time of Achievement & 4 & 3 & 3,5 & Feasible \\
\hline$\quad$ Average & & & 3.7 & Very Feasible \\
\hline
\end{tabular}

In this assessment, the experts gave a score of 3.7. It showed that the syllabus was very feasible to be used in the EFS learning process. Furthermore, during the interview process, the experts only commented that the syllabus was very appropriate to use.

Furthermore, the experts assessed the EFS instructional material draft 3 that had been developed. The following table was the result of the assessment:

Table 9: Feasibility Test of Instructional Material Draft 3

\begin{tabular}{|c|c|c|c|c|c|}
\hline Dimension & Indicators & 1 & 2 & Average & Explanation \\
\hline \multirow{3}{*}{$\begin{array}{l}\text { Aim and } \\
\text { Approach }\end{array}$} & Objectives & 4 & 4 & 4 & Feasible \\
\hline & Student's need & 4 & 4 & 4 & Very Feasible \\
\hline & Learning style & 3 & 3 & 3 & Feasible \\
\hline \multirow{3}{*}{$\begin{array}{l}\text { Design and } \\
\text { Organization }\end{array}$} & Course package & 4 & 4 & 4 & Very Feasible \\
\hline & Content organization & 4 & 4 & 4 & Feasible \\
\hline & Content sequencing & 4 & 4 & 4 & Feasible \\
\hline \multirow{2}{*}{$\begin{array}{l}\text { Language } \\
\text { Content }\end{array}$} & Grammar & 4 & 3 & 3,5 & Feasible \\
\hline & Vocabulary & 3 & 3 & 3 & Feasible \\
\hline \multirow[t]{4}{*}{ Skills } & Listening & 3 & 4 & 3,5 & Very Feasible \\
\hline & Speaking & 4 & 4 & 4 & Very Feasible \\
\hline & Reading & 4 & 4 & 4 & Feasible \\
\hline & Writing & 4 & 4 & 4 & Feasible \\
\hline \multirow[t]{3}{*}{ Topic } & Interesting material & 4 & 4 & 4 & Very Feasible \\
\hline & Material variety & 4 & 4 & 4 & Very Feasible \\
\hline & $\begin{array}{l}\text { Awareness and } \\
\text { experience. }\end{array}$ & & & & Very Feasible \\
\hline \multirow[t]{3}{*}{ Methodology } & Suitability of approach & 4 & 4 & 4 & Feasible \\
\hline & Suitability of techniques & 3 & 4 & 3,5 & Very Feasible \\
\hline & Average & & & 3.7 & Feasible \\
\hline
\end{tabular}




\section{Didik Hariyadi Raharjo}

Based on quantitative data from the experts' assessment in the table above, the researcher could conclude that the design of the EFS instructional material model through Moodle draft 3 was very feasible to use. The same result was also obtained in the interview process that was carried out on EFS draft 3 instructional material draft 3.

\section{DISCUSSION}

As explained earlier, the feasibility test of the developed EFS instructional material was carried out 3 times. Based on the first expert judgment, it could be concluded that the EFS syllabus draft 1 developed had a score of 3.5. It showed that the syllabus was very suitable to be used in the learning process. Furthermore, in the interview process, the experts gave a suggestion to change the form of assessment indicators of 4 English language skills used previously to analytic assessments form with descriptive indicators. It was aimed to provide clearer marking marks for the lecturer in the EFS courses. Liao \& Hsu (2014) found that analytical rubric on writing could increase the awareness of the structure, improve the organization of writing, and remind students for lexical use and grammar. Meanwhile, Quintero, Guzmán, \& Guzmán, (2017) stated that by using the analytic assessment rubric, the assessors will pay more attention to the assessment criteria given. The second suggestion was about the form of syllabus used. In the EFS syllabus draft 1, the researcher used the semester form syllabus and based on the advice of the experts, the researcher changed the syllabus form into meeting syllabus or in Indonesian learning context was known as Lesson Plan (RPP). This was intended to provide wider space to explain the whole learning process so that the activities of lecturers and students could be clearly described in each phase of inquiry learning on EFS instructional material. By using RPP the lecturer would get an overview of the learning process that would be carried out easily and systematically. In addition, lecturer could modify each learning process that was done so that it was not monotonous and boring. (Al-Tabany, 2014); (Rusman, 2012).

In the evaluation of instructional material draft 1 , the experts gave a score of 3.25. It showed that the instructional material was feasible to be used in the EFS learning process. Based on the interview, the experts advised the researcher to change the entire instructional sentences in the exercises and evaluations by adjusting them to the assessment criteria contained in the assessment rubric. It was aimed to provide information to students about the assessment criteria used. The second change was to add a reference sub section to the EFS instructional material website. While the third change was the addition of illustrations needed in EFS instructional material developed. 
After making various changes to the syllabus and instructional materials based on the experts' recommendations on the evaluation of instructional material draft 1 , the researcher returned to conduct a feasibility test on the EFS instructional material draft 2 that had been developed. In the EFS syllabus draft 2 assessment, the experts gave a score of 3.5. It showed that the syllabus draft 2 was appropriate to be used in the EFS learning process. Furthermore, based on the results of interview that had been conducted, the experts did not provide much comment about the syllabus and the experts only indicated that the syllabus was very good in quality and was suitable to use in EFS learning. In the assessment of EFS instructional material draft 3 , the experts gave a score of 3.5 which meant that the instructional material was already very feasible to be used in the EFS learning process. In the interview process, the experts also did not provide much comment about this instructional material. The experts also gave an indication that this instructional material was very feasible to be used in the EFS learning process.

After that, the researcher applied the EFS syllabus and instructional material draft 2 in a small group test. Based on the small group test, the researcher could conclude that some of the files in the EFS instructional material were too large and the illustrative images needed to strengthen the students' understanding about the materials contained in EFS.

In the assessment of EFS syllabus draft 3, the experts gave a score of 3.7. It showed that the syllabus was very feasible to be used in the EFS learning process. Furthermore, during the interviewing process, the experts only commented that the syllabus was very appropriate to use. Meanwhile based on the assessment of EFS instructional material through Moodle draft 3 , it showed that it was very feasible to use. Furthermore, the researcher conducted interviews with experts regarding the design of EFS instructional material draft 3 . In line with the results of interviews conducted it showed that the instructional material developed was very feasible to use. Furthermore, the experts did not provide comments, suggestions or revisions to the draft 3 EFS instructional material.

Based on all the qualitative and quantitative data above, the researcher can conclude that the EFS instructional material through Moodle that was developed was very feasible to be implemented for ASTRI Budi Luhur Students Jakarta. It was in line with the results of the research conducted by Wulandari (2015), that Moodle instructional material was in accordance with the principles of Computer Assisted Language Learning (CALL) and the principle of 9 stages of learning delivered by Gagne. 


\section{CONCLUSION AND SUGGESTION}

The conclusion of this research is that the condition of the existing of EFS instructional material in ASTRI Budi Luhur was not feasible because it is not equipped with Listening material and guidebook for the students and lecturers. The vocabulary and Grammar in this instructional material are inadequate for secretarial students. It only contains 3 English skills, (Reading, Speaking and Writing).

The EFS instructional material has been validated by two experts, those are: ESP expert and Moodle expert. The result showed that the instructional material was feasible with several improvements. Product feasibility test in this research was carried out 3 times. Each test was carried out after revising the draft instructional material based on input provided by experts. In the last feasibility test the experts gave a score of 3.7 for the syllabus and 3.7 for the developed instructional material. These score indicated that both the syllabus and EFS instructional material developed were very feasible to be applied in EFS learning in ASTRI Budi Luhur Jakarta.

Based on the findings of this research, the researcher could provide several recommendations:

1. For syllabus and instructional material developers, they could explore the shortcomings of the developed EFS instructional material products to be developed in further researches.

2. For EFS lecturers in ASTRI Budi Luhur, they could use EFS instructional material products that have been developed.

3. For ASTRI Budi Luhur, to be able to provide facilities to lecturers in the development and feasibility of the instructional material products that had been produced.

\section{REFERENCES}

Al-Tabany, T. I. B. (2014). Mendesain model pembelajaran inovatif, progresif, dan kontekstual. In Prenadamedia Group.

Beth, L. (2019). TLM: Teaching/Learning Materials. Retrieved from: https://www.thoughtco.com/tlm-teaching-learning-materials-2081658

Celce. M. \& Murcia E. O. (2000). Discourse and Context in Language Teaching. New York: Combridge University Press

Clark, R. C., \& Mayer, R. E. (2011). e-Learning and the Science of Instruction. In e-Learning and the Science of Instruction: Proven Guidelines for Consumers and Designers of Multimedia Learning: Third Edition. https://doi.org/10.1002/9781118255971

Cresswell, J. W., Plano-Clark, V. L., Gutmann, M. L., \& Hanson, W. E. (2003). Advanced mixed methods research designs. Handbook of Mixed Methods in Social and Behavioral Research. 
Feasibility Test of English Instructional Materials for...

Cunningsworth, A. (2000). Choosing Your Course Book. Oxford: Macmilan Publisher

Genova, M.M. (2019). Designing an effective digital learning environment for teaching english through literature: the learning experience of bulgarian students. Journal of e-Learning and Knowledge Society. Vol. 15, n.2, ISSN: 1826-6223 | eISSN: 1971-8829

Giri, P., Artini, L. P., \& Padmadewi, N. N. (2018). Natural Approach in English Classes in Primary Schools: Teachers' Perception and Implementation. Jurnal Pendidikan Bahasa Inggris Indonesia. https://doi.org/10.23887/jpbi.v6i2.2709

Hutchinson, T., \& Waters, A. (1988). English for Specific Purposes: A Learning-Centred Approach. The Modern Language Journal, 72(1), 73. https://doi.org/10.2307/327576

Liao, H. C., \& Hsu, L. (2014). Using an analytical rubric to improve the writing of EFL college students. Asian EFL Journal.

Mahajan, V., Linstone, H. A., \& Turoff, M. (1976). The Delphi Method: Techniques and Applications. Journal of Marketing Research. https:/ / doi.org/10.2307/3150755

Martins, C. G. D. F. M., Levis, J. M., \& Borges, V. M. C. (2016). The design of an instrument to evaluate software for EFL/ESL pronunciation teaching. Ilha Do Desterro. https://doi.org/10.5007/21758026.2016v69n1p141

Mc.Grath, I. (2013). (2013). Instructional materials and the Roles of EFL/ESL Teachers: Practice and Theory. New Delhi: Bloomsbury Academic

Nunan, D. (2004). Task-Based Language Teaching. In Task-Based Language Teaching. https://doi.org/10.1017/cbo9780511667336

Nurhamsih, Y., \& Syahrial, S. (2018). Evaluation of English Teaching Materials used at a Vocational High School Based on Cunningsworth's Checklist. JOALL (Journal of Applied Linguistics $\mathcal{E}$ Literature). https:// doi.org/10.33369/joall.v3i2.6830

Nurwardani, et al. (2016). Panduan Penyusunan Kurikulum Perguruan Tinggi. Direktorat Jenderal Pembelajaran dan Kemahasiswaan Kementerian Riset Teknologi dan Pendidikan Tinggi

Quintero, E. F. G., Guzmán, N. P. T., \& Guzmán, R. R. (2017). Assessing EFL university students' writing: A study of score reliability. Revista Electronica de Investigacion Educativa. https:/ / doi.org/10.24320/redie.2017.19.2.928

Rahamdina, Alamsyah. H \& Sofyan D. (2019). Need analysis of english for tour and travel department of vocational high school in bengkulu city. JOALL (Journal of Applied Linguistics and Literature), Vol. 4(1),doi: 10.33369/joall.v4i1.6303

Richards, J. C., \& Schmidt, R. (2010). Longman dictionary of language 
teaching \& applied linguistics. In Proceedings of the 21st Asian Pacific Weed Science Society (APWSS) Conference, 2-6 October 2007, Colombo, Sri Lanka.

Rusman. (2012). Model-model Pembelajaran Mengembangkan Profesionalisme Guru. In Jakarta: Rajawali Pers.

Salisna, R., Harahap, A., \& Sofyan, D. (2019). Need analysis of english for tour and travel department of vocational high school in bengkulu city. JOALL (Journal of Applied Linguistics $\mathcal{E}$ Literature). https://doi.org/10.33369/joall.v4i1.6303

Sugiyono, P. D. (2016) Metode penelitian kuantitatif, kualitatif,dan R\&D. , Alfabeta, cv.

Tomlinson, B. (2011). Introduction: principles and procedures of materials development. In Materials Development in Language Teaching.

Wulandari, M. (2015). Moodle-Based Learning Model for Paragraph Writing Class. Language and Language Teaching Journal. https://doi.org/10.24071/1lt.2015.180201

Yatimah, Durotul. (2009). Sekretaris Modern. Jakarta: Eska Media 